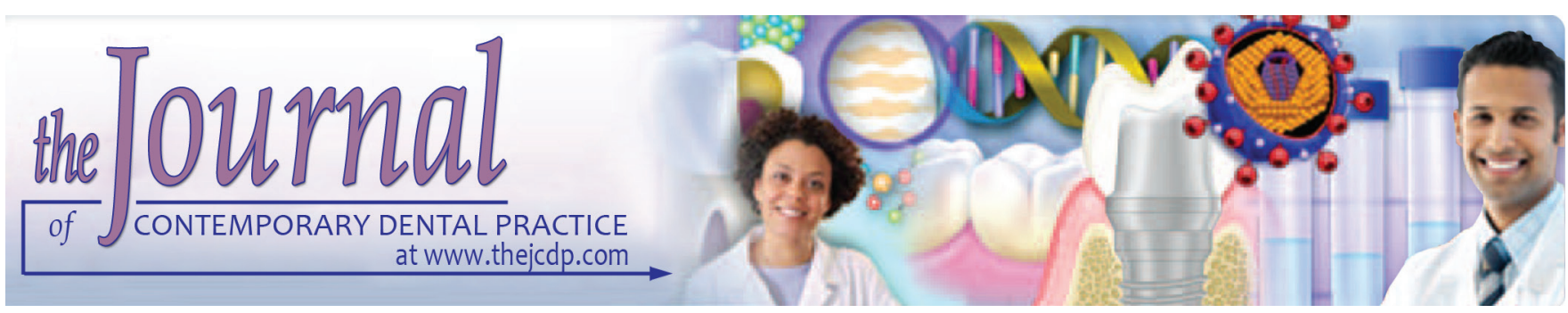

\title{
Evaluation of Cellular Proliferative Activity in Patients with Actinic Cheilitis through Silver-stained Nucleolar Organizer Region Method
}

${ }^{1}$ Sâmela Martins, ${ }^{2}$ Bernardo Zoehler, ${ }^{3}$ Carmen S Busin, ${ }^{4}$ Silas AJ de Freitas Filho, ${ }^{5}$ Luiz R Paranhos, ${ }^{6}$ Maria SS Linden

${ }^{7}$ Marcos E de Bittencourt, ${ }^{8} \mathrm{~J}$ ão P de Carli

\begin{abstract}
Introduction: Actinic cheilitis (AC) is a lesion potentially malignant that affects the lips after prolonged exposure to solar ultraviolet (UV) radiation. The present study aimed to assess and describe the proliferative cell activity, using silver-stained nucleolar organizer region (AgNOR) quantification proteins, and to investigate the potential associations between AgNORs and the clinical aspects of $\mathrm{AC}$ lesions.
\end{abstract}

Materials and methods: Cases diagnosed with AC were selected and reviewed from Center of Histopathological Diagnosis of the Institute of Biological Sciences, Passo Fundo University, Brazil. Clinical data including clinical presentation of the patients affected with AC were collected. The AgNOR techniques were performed in all recovered cases. The different microscopic areas of interest were printed with magnification of $\times 1000$, and in each case, 200 epithelial cell nuclei were randomly selected. The mean quantity in each nucleus for NORs was recorded. One-way analysis of variance was used for statistical analysis.

Results: A total of 22 cases of AC were diagnosed. The patients were aged between 46 and 75 years (mean age: 55 years). Most of the patients affected were males presenting asymptomatic white plaque lesions in the lower lip. The mean value quantified

\footnotetext{
${ }^{1,6-8}$ Department of Dentistry, University of Passo Fundo, Passo Fundo, Rio Grande do Sul, Brazil

${ }^{2,3}$ Department of Biological Sciences, University of Passo Fundo Passo Fundo, Rio Grande do Sul, Brazil

${ }^{4}$ Department of Surgery, Stomatology, Pathology and Radiology (Area of Pathology), Bauru School of Dentistry, University of São Paulo, Bauru, São Paulo, Brazil

${ }^{5}$ Department of Preventive and Community Dentistry, School of Dentistry, Federal University of Uberlândia, Minas Gerais, Brazil

Corresponding Author: João P de Carli, Department of Dentistry, University of Passo Fundo, Passo Fundo, Rio Grande do Sul, Brazil, Phone: +555433168402, e-mail: joaodecarli@ upf.br
}

for AgNORs was $2.4 \pm 0.63$, ranging between 1.49 and 3.82 . No statistically significant difference was observed associating the quantity of AgNORs with the clinical aspects collected from the patients $(p>0.05)$.

Conclusion: The present study reports the lack of association between the proliferative cell activity and the clinical aspects observed in patients affected by AC through the quantification of AgNORs.

Clinical significance: Knowing the potential relation between the clinical aspects of $\mathrm{AC}$ and the proliferative cell activity quantified by AgNORs could play a significant role toward the early diagnosis of malignant lesions in the clinical practice.

Keywords: Actinic cheilitis, Proliferative cell activity, Silverstained nucleolar organizer regions.

How to cite this article: Martins S, Zoehler B, Busin CS de Freitas FilhoSAJ, Paranhos LR, Linden MSS, de BittencourtME, de Carli JP. Evaluation of Cellular Proliferative Activity in Patients with Actinic Cheilitis through Silver-stained Nucleolar Organizer Region Method. J Contemp Dent Pract 2018;19(4):384-388.

Source of support: Nil

Conflict of interest: None

\section{INTRODUCTION}

Actinic cheilitis is a disease with lesions potentially malignant caused by the prolonged exposure to solar UV radiation. The lesion affects mainly the lips of Caucasian men that work outdoors. ${ }^{1,2}$ Ultraviolet radiation leads to injuries to the genetic material of epithelial cells and results in morphological alterations. ${ }^{1,3,4}$

Oral biopsy is an essential part in the diagnosis of AC. ${ }^{4}$ Microscopically, AC lesions present epithelial alterations that include variations in thickness, deposition of keratin, and dysplasia, while the lamina propria shows solar elastosis and chronic inflammatory infiltrate. ${ }^{5}$ Besides the morphological alterations, the diagnosis of $\mathrm{AC}$ is also found on the clinical aspects of the lesions and patient's demographic data. ${ }^{6}$ 
Predicting exactly the progression of AC is not possible. ${ }^{7}$ However, it is important to consider its potential malignance, ${ }^{8}$ which may vary from $2^{9}$ to $16.9 \%{ }^{6}$ For major predictability, the level of epithelial dysplasia is used to assess the related progression and transformation of oral lesions. On the contrary, the scientific literature is controversial once the level of dysplasia is not always associated with potential malignancy. ${ }^{10}$ In addition, predicting cellular atypia is a challenging procedure for the clinician because the level of epithelial dysplasia does not correspond to specific clinical characteristics of AC lesions. ${ }^{11}$

Assessing cellular proliferation through the quantification of AgNORs (proteins related to nucleolar organizer regions) emerged as an approach highly reliable for determining the level of dysplasia, predicting the potential for malignant transformation, ${ }^{12}$ and distinguishing between benign and malignant lesions. ${ }^{13}$ Marking NORs consists in detecting proteins associated with transcriptional activity through the impregnation of colloidal silver. ${ }^{13,14}$ Specifically, this procedure reveals the active position of NOR transcription within the interphase nucleus. Visually, this phenomenon is translated in black spots detectable on microscopic examination. ${ }^{13,14}$

In general, the squamous cell carcinoma of the lip manifests clinically as an ulceroinfiltrative lesion. ${ }^{15}$ However, no clinical aspect enables the differentiation between a malignant lesion in initial stage from an AC lesion. ${ }^{2,7}$ Currently, the scientific literature lacks studies on the correlation between the clinical aspects of AC lesions and the proliferative cell activity quantifying AgNORs. The present study aimed first to assess and describe the proliferative cell activity in AC lesions through the quantification of AgNORs in the epithelial tissue. Second, it aimed to investigate the potential associations between the quantity of AgNORs and the clinical aspects of AC.

\section{MATERIALS AND METHODS}

This study was conducted after the approval of the Committee of Ethics in Research of Passo Fundo University under the protocol \#145/2011.

\section{Study Design and Sampling}

An observational and analytical study on the clinical records of the Center for Histopathological Diagnosis of the Institute of Biological Sciences, Passo Fundo University, Brazil, was performed using a database registered between 1990 and 2015.

A database of 3,185 clinical records was screened retrospectively without limiting patients' age and sex. All the cases diagnosed histologically as AC were retrieved.

\section{Methods}

Initially, all the clinical data of the patients were collected. It included information regarding age, sex, type of lesion, symptoms, texture, borders of the lesion, color of the lesions, and time of progression. Information on occupational activity and time of exposure to sunlight also was collected. The diagnoses of AC were confirmed preparing and analyzing $4 \mu \mathrm{m}$ sections stained in hematoxylin and eosin (H\&E) by two examiners (JPD, CSB). Criteria for the diagnosis of $\mathrm{AC}$ were epithelial alterations on the lip mucosa, and in the lamina propria, the presence of solar elastosis, and inflammatory infiltrate from mild to severe. ${ }^{2,6}$ The dysplasia classification was performed in according with the World Health Organization. ${ }^{16}$

The AgNOR detection $4 \mu \mathrm{m}$ sections of formalin-fixed and paraffin-embedded tissues were obtained from each case. The sections were dewaxed in xylene and rehydrated in solutions with decreasing concentrations of ethanol. The following were the silver staining methods performed according to Ploton et al. ${ }^{17}$

The different microscopic areas of interest were printed with the magnification of $\times 1000$. In these images, NORs under immersion were counted in each case considering 200 epithelial cell nuclei selected randomly. The mean quantity in each nuclei for NORs was recorded. This AgNOR analysis was performed by two other independent examiners (SM, BZ).

\section{Data Analysis}

After exploring the data descriptively, one-way analysis of variance was applied to correlate the clinical aspects of AC lesions with the histochemical data. Correlations significant statistically were considered when $p<0.05$. Statistics were performed using Statistical Package for the Social Sciences version 18.0 (IBM, Armonk, New York, USA) software package.

\section{RESULTS}

A total of 22 cases of AC were diagnosed between 1990 and 2015. Twenty cases involved male patients, while two involved females. The clinical aspects in these cases are reported in Table 1.

The patients involved were aged from 46 to 75 years (mean age: 55 years). Thirty patients worked as farmers $(59.10 \%)$, two as assistants in farmhouses $(9.10 \%)$, one as a mechanic (n: $1 ; 4.54 \%)$, and one as a teacher (n: 1 ; $4.54 \%$ ). The remaining 5 patients $(22.72 \%)$ did not report their labor activities. Seventeen patients $(77.27 \%)$ worked frequently under the sunlight. The mean time for lesion progression was 11.14 months.

In general, the mean quantity of AgNORs was 2.4 \pm 0.63 ranging from 1.49 to 3.82 . The mean quantity of 
Table 1: Clinical aspects of patients with $A C$

\begin{tabular}{|c|c|}
\hline Clinical aspects & $n(\%)$ \\
\hline \multicolumn{2}{|l|}{ Age (years) } \\
\hline $46-50$ & $3(13.64)$ \\
\hline $51-60$ & $15(68.18)$ \\
\hline $61-75$ & $4(18.18)$ \\
\hline \multicolumn{2}{|l|}{ Sex } \\
\hline Males & $20(90.90)$ \\
\hline Females & $2(9.10)$ \\
\hline \multicolumn{2}{|l|}{ Location } \\
\hline Lower lip & $22(100.00)$ \\
\hline \multicolumn{2}{|c|}{ Time of progression (months) } \\
\hline $1-10$ & $11(50.00)$ \\
\hline 12 & $5(22.72)$ \\
\hline 24 & $4(18.18)$ \\
\hline 48 & $2(9.10)$ \\
\hline \multicolumn{2}{|l|}{ Type of lesion } \\
\hline Plaque & $14(63.62)$ \\
\hline Crust & $3(13.64)$ \\
\hline Ulcer & $3(13.64)$ \\
\hline Nodule & $2(9.10)$ \\
\hline \multicolumn{2}{|l|}{ Texture } \\
\hline Plain & $11(50.00)$ \\
\hline Rough & $7(31.82)$ \\
\hline Ulcerated & $3(13.64)$ \\
\hline Rough and ulcerated & $1(4.54)$ \\
\hline \multicolumn{2}{|l|}{ Symptoms } \\
\hline Present & $4(18.18)$ \\
\hline Absent & $12(54.54)$ \\
\hline Not reported & $6(27.28)$ \\
\hline \multicolumn{2}{|l|}{ Borders of the lesion } \\
\hline Undefined & $12(54.54)$ \\
\hline Well-defined & $8(36.36)$ \\
\hline Not reported & $2(9.10)$ \\
\hline \multicolumn{2}{|l|}{ Color of the lesion } \\
\hline White & $17(77.28)$ \\
\hline White and red & $5(22.72)$ \\
\hline \multicolumn{2}{|l|}{ Type of biopsy } \\
\hline Excisional & $8(36.36)$ \\
\hline Incisional & $4(18.18)$ \\
\hline Not reported & $10(45.46)$ \\
\hline
\end{tabular}

AgNORs expressed in each patient separately is presented in Table 2. Representative pictures from AgNOR staining are shown in Figure 1.

No statistically significant association $(p>0.05)$ was observed correlating clinical and histochemical (quantity of AgNORs) aspects of AC (Table 3).

\section{DISCUSSION}

In the present study, the association between the clinical aspects of AC lesion and its proliferative cell activity was investigated as an attempt to improve the diagnostic tools and prognosis of these lesions. In addition, the association between the quantity of AgNORs and the clinical manifestation of these lesions was also investigated and
Table 2: Mean quantity of AgNORs for each case of AC

\begin{tabular}{clll}
\hline Case & Mean AgNORs & Case & Mean AgNORs \\
\hline 1 & 3.23 & 12 & 2.07 \\
2 & 1.72 & 13 & 2.38 \\
3 & 2.02 & 14 & 1.49 \\
4 & 2.01 & 15 & 3.82 \\
5 & 1.92 & 16 & 3.63 \\
6 & 1.91 & 17 & 2.58 \\
7 & 2.01 & 18 & 2.21 \\
8 & 2.50 & 19 & 2.08 \\
9 & 2.66 & 20 & 3.42 \\
10 & 2.45 & 21 & 2.79 \\
11 & 1.89 & 22 & 2.01 \\
\hline
\end{tabular}
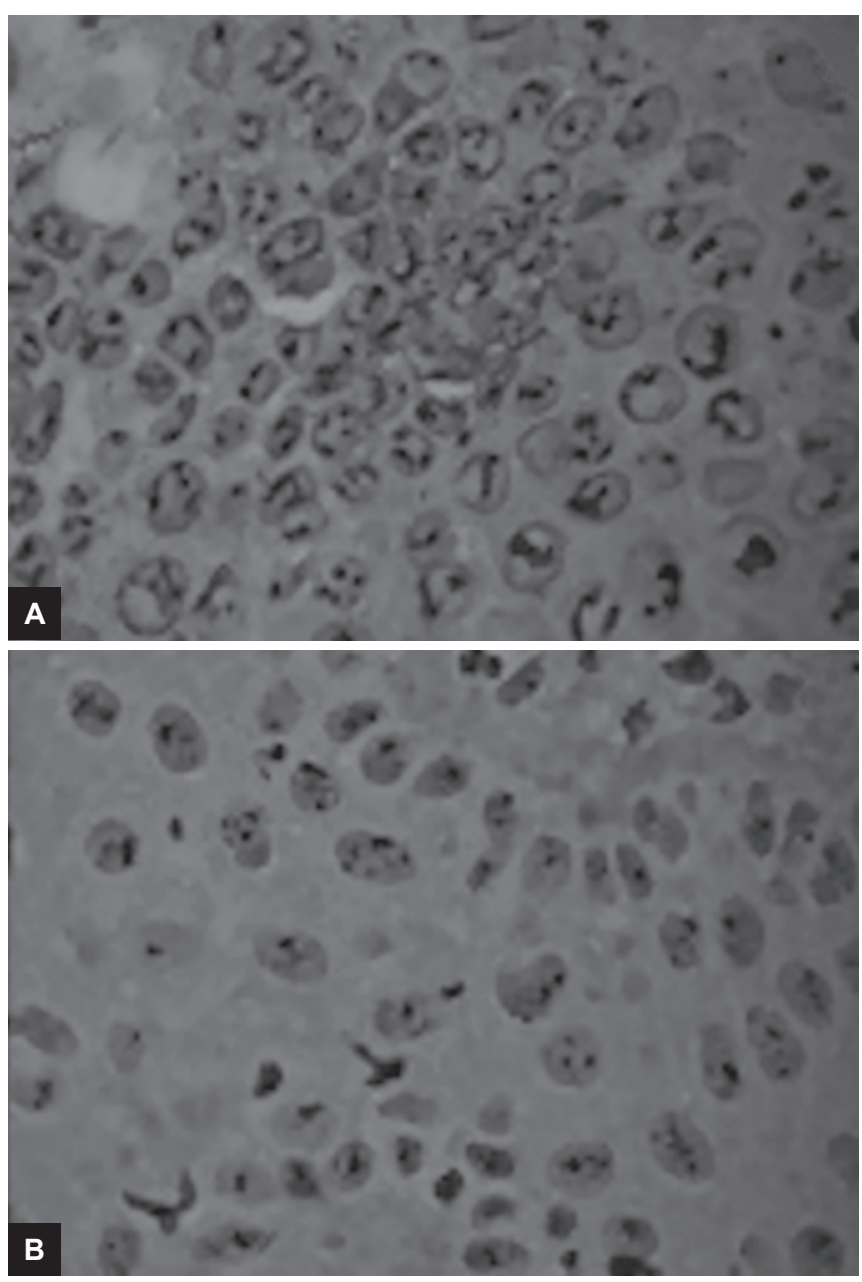

Figs 1A and B: High (A) and low (B) AgNOR staining in the nucleus of the epithelial cells

Table 3: Correlation between the mean quantity of AgNORs and the clinical aspects expressed by one-way ANOVA test

\begin{tabular}{ll}
\hline Clinical aspects & $p$-value \\
\hline Age & 0.74 \\
Sex & 0.398 \\
Time of progression & 0.449 \\
Type of lesion & 0.851 \\
Texture & 0.79 \\
Symptoms & 0.118 \\
Border of the lesion & 0.308 \\
Color of the lesion & 0.669 \\
\hline
\end{tabular}


resulted with no positive evidence. Proliferative activity by AgNOR staining has been studied in potentially malignant lesions of the oral mucosa. . $^{12,13,18}$

Most of the patients addressed in the current study were aged 51 to 60 years when diagnosed with AC. The main factor leading to $\mathrm{AC}$ is the exposure to solar radiation for a long period. ${ }^{6,19}$ More specific, the exposure to solar radiation consists of a risk factor highly prevalent in adults aged in the sixth and seventh decades of life. It is estimated that the patients sampled in this study were exposed to solar radiation for a long time, enabling a slow development of the lesions. In general, the severity level of AC lesions is associated with the time of exposure under solar radiation. ${ }^{20}$

The higher prevalence of $\mathrm{AC}$ among males detected in the present study is also supported in other studies in the scientific literature. This finding is justified on the fact that most of the labor activities outdoors and under exposure to solar radiation are performed by men. ${ }^{3,6,9}$ Specifically, in relation to the labor activities, a high number of farmers affected by AC was detected within the present study, confirming the outcomes reported previously by Lemos et $\mathrm{al}^{4}$ and Martins-Filho et al. ${ }^{19}$ Daily activities performed in this context play an essential role toward the development of lip cancer. ${ }^{15}$ The present study encourages preventive and educational services designed for patients in risk groups, such as farmers.

Apparently, AC affects more Caucasian patients. This hypothesis was confirmed within the present sample and also by previous studies. ${ }^{9,21,22}$ Caucasian patients have less melanin pigmentation. Consequently, the skin cells are more exposed to UV radiation. In addition, the carcinogenic process on skin is similar to the lip, ${ }^{23}$ explaining the prevalence rate of $\mathrm{AC}$ in Caucasians. ${ }^{24}$ Concerning the anatomic location of occurrence, $\mathrm{AC}$ lesions affect more the lower lip because of the direct exposure to the solar radiation..$^{25,26}$

According to Savage et $\mathrm{al}^{27}$ the fundamental lesion in $\mathrm{AC}$ is frequently a leukoplastic plaque. In the present study, leukoplastic plaques were observed in 14 patients (63.64\%). Considering the color of the lesions, most were whitish (n: $17 ; 77.27 \%$ ). However, erythematous areas with edema may be found in AC lesions with moderate severity. ${ }^{28}$ Simultaneous whitish plaque with erythematous areas may also be found. ${ }^{19,24}$ Usually, AC lesions are asymptomatic, ${ }^{20}$ but patients may complain differently (e.g., reporting burning and itching). ${ }^{19}$ In the present study, the majority of patients did not report symptoms.

Oral biopsy is applied for the diagnostic confirmation of AC. This procedure is especially justified due to the several differential diagnoses found clinically, such as leukoplakia, hemangioma, and mucocele. ${ }^{4}$ Based on that the treatment plan for AC lesions must not be supported exclusively by clinical findings. ${ }^{1}$ In 10 patients (45.46\%), the type of biopsy was not mentioned in the dental record. In specific, exfoliative cytology was not performed in the patients sampled. The present study highlights the need for a protocol for interventions on AC lesions and the importance of registering properly the clinical information in the dental records.

When quantified, the mean AgNORs found in the present study were lower than the mean observed by de Rosa et $\mathrm{al}^{29}$ - up to the present, the only study quantifying AgNORs in AC lesions. Yet, when associated with the clinical aspects of AC lesions, the AgNORs did not reveal statistically significant differences $(p>0.05)$. This outcome indicates that proliferative cell activity does not have specific clinical aspects in lip lesions potentially malignant caused by actinic injury.

Altemani et $\mathrm{al}{ }^{13}$ showed limitations in the quantification of AgNORs for distinguishing pseudocarcinomatous hyperplasia and oral epidermoid carcinoma. Fabbrocini et $\mathrm{al}^{30}$ observed that AgNORs are marking increase with the decrease of cell differentiation in epidermoid carcinomas of the lower lip. The literature suggests that low-risk epithelial dysplasia has a mean quantity of AgNORs significantly lower than the high-risk dysplasias. It indicates that the quantification of NORs may be useful in determining the severity level of dysplasias and in stressing the risk for malignant transformation of oral lesions. ${ }^{12}$ Moreover, the mean quantity of AgNORs and their sizes increase considerably from lesions potentially malignant to carcinomas. ${ }^{12,29}$ Clinical aspects of these lesions did not reveal an association with the level of dysplasia in $\mathrm{AC}^{24}$ Considering the scarce studies in the field and the lack of association between the clinical and histochemical aspects of AC, public health policies are necessary for the education of patients in the early detection and treatment of AC.

\section{CONCLUSION}

The present study described the cellular proliferation and the different clinical aspects of AC lesions. The outcomes observed clinically do not have relation with the proliferative cell activity when assessed through the quantification of AgNORs. Further studies are necessary on the investigation of diagnostic tools and the prognosis of AC lesions.

\section{CLINICAL SIGNIFICANCE}

Investigating the potential association between the clinical aspects of $\mathrm{AC}$ and the proliferative cell activity quantified by AgNORs could benefit the clinical practice, especially in the early diagnosis of malignant lesions. Considering the fact that no association was observed in this context, the present study contributes to the clinical 
practice, indicating that other approaches must be developed and investigated for the early diagnosis of malignant lesions related to AC.

\section{REFERENCES}

1. Araújo CP, Vidal MT, GurgelCA, Ramos EA, Barbosa-Júnior AA, Ramalho LM, Santos JN. Queilite actínica: Um estudo de 35 casos com destaque para os aspectos morfológicos. RPG Rev Pós Grad 2012;19(1):21-27.

2. Vieira RA, Minicucci EM, Marques ME, Marques SA. Actinic cheilitis and squamous cell carcinoma of the lip: clinical, histopathological and immunogenetic aspects. An Bras Dermatol 2012 Jan-Feb;87(1):105-114.

3. de Souza Lucena EE, Costa DC, da Silveira EJ, Lima KC. Prevalence and factors associated to actinic cheilitis in beach workers. Oral Dis 2012 Sep;18(6):575-579.

4. Lemos MA, Maciel TA, Matos FR, Amorim AG, Galvão HC. Queilite actínica: estudo Clinicopatológico de 46 Casos. UNOPAR Cient Ciênc Biol Saúde 2009;11(3):9-12.

5. Arnaud RR, Soares MS, Paiva MA, Figueiredo CR, Santos MG, Lira CC. Queilite actínica: avaliação histopatológica de 44 casos. Rev Odontol UNESP 2014 Nov-Dec;43(6):384-389.

6. Markopoulos A, Albanidou-Farmaki E, Kayavis I. Actinic cheilitis: clinical and pathologic characteristics in 65 cases. Oral Dis 2004 Jul;10(4):212-216.

7. Wood NH, Khammissa R, Meyerov R, Lemmer J, Feller L. Actinic cheilitis: a case report and a review of the literature. Eur J Dent 2011 Jan;5(1):101-106.

8. Rossoe EW, Tebcherani AJ, Sittart JA, Pires MC. Actinic cheilitis: aesthetic and functional comparative evaluation of vermilionectomy using the classic and $\mathrm{W}$-plasty techniques. An Bras Dermatol 2011 Jan-Feb;86(1):65-73.

9. Piñera-Marques K, LorençoSV, Silva LF, Sotto MN, Carneiro PC. Actinic lesions in fishermen's lower lip: clinical, cytopathological and histopathologic analysis. Clinics (Sao Paulo) 2010 Apr;65(4):363-367.

10. Dost F, Lê Cao K, Ford PJ, Ades C, Farah CS. Malignant transformation of oral epithelial dysplasia: a real-world evaluation of histopathologic grading. Oral Surg Oral Med Oral Pathol Oral Radiol 2014 Mar;117(3):343-352.

11. Reibel J. Prognosis of oral pre-malignant lesions: significance of clinical, histopathological, and molecular biological characteristics. Crit Rev Oral Biol Med 2003 Jan;14(1):47-62.

12. Tomazelli KB, Modolo F, Rivero ER. Evaluation of AgNORs in oral potentially malignant lesions. J Oncol 2015 Aug;2015:218280.

13. Altemani AM, Crespo A, Cardinalli IA, Norato D. Nucleolar organizer region (NORs) in pseudocarcinomatous hyperplasia and squamous cell carcinoma of the oral mucosa. Sao Paulo Med J 1995 Jan-Feb;113(1):693-697.

14. Buys $\mathrm{CH}$, Osinga J. Abundance of protein-bound sulfhydryl and disulfide groups at chromosomal nucleolus organizing regions: a cytochemical study on the selective silver staining of NORs. Chromosoma 1980 Feb;77(1):1-11.

15. dos Santos LR, Cernea CR, Kowalski LP, Carneiro PC, Soto MN, Nishio S, Hojaij FC, Dutra Júnior A, Britto e Silva Filho G, Ferraz AR. Squamous-cell carcinoma of the lower lip: a retrospective study of 58 patients. Sao Paulo Med J 1996 Mar-Apr; 114(2):1117-1126.
16. Thompson L. World health organization classification of tumours: pathology and genetics of head and neck tumours. Ear Nose Throat J 2006 Feb;85(2):74.

17. Ploton D, Menager M, Jeanessonn P, Himber G, Pigeon F, Adnet JJ. Improvement in the staining and in the visualization of the argyrophilic proteins of the nucleolar organizer regions at the optical level. Histochem J 1986 Jan;18(1):5-14.

18. Carli JP, Silva SO, Linden MS, Busin CS, Paranhos LR, Souza PH. Evaluation of cellular proliferative activity in patients with oral lichen planus and hepatitis $C$ through AgNOR method. Braz Dent J 2014 Nov-Dec;25(6):461-465.

19. Martins-Filho PR, Da Silva LC, Piva MR. The prevalence of actinic cheilitis in farmers in a semi-arid northeastern region of Brazil. Int J Dermatol 2011 Sep;50(9):1109-1114.

20. Miranda AM, Soares LG, Ferrari TM, Silva DG, Falabella ME, Tinoco EM. Prevalence of actinic cheilitis in a population of agricultural sugarcane workers. Acta Odontol Latinoam 2012 Oct;25(2):201-206.

21. Silva FD, Daniel FI, Grando LJ, Calvo MC, Rath IB, Fabro SM. Estudo da prevalência de alterações labiais em pescadores da ilha de Santa Catarina. Rev Odonto Cienc 2006 Jan-Mar; 21(51):37-42.

22. Cavalcante AS, Anbinder AL, Carvalho YR. Actinic cheilitis: clinical and histological features. J Oral Maxillofac Surg 2008 Mar;66(3):498-503

23. Goldson A, Henschke U, Leffall LD, Schneider RL. Is there a genetic basis for the differences in cancer incidence between Afro-Americans and Euro-Americans? J Natl Med Assoc 1981 Aug;73(8):701-706.

24. de Santana Sarmento DJ, da Costa Miguel MC, Queiroz LM, Godoy GP, da Silveira EJ. Actinic cheilitis: clinicopathologic profile and association with degree of dysplasia. Int J Dermatol 2014 Apr;53(4):466-472.

25. Osterne RL, Costa FW, Mota MR, Vidal Patrocínio RM, Alves AP, Soares EC, Sousa FB. Lip lesions in a Brazilian population. J Craniofac Surg 2011 Nov;22(6):2421-2425.

26. Souza RL, Fonseca-Fonseca T, Oliveira-Santos CC, Corrêa GT, Santos FB, Cardoso CM, Sant'Ana-Haikal D, Guimarães AL, Batista-De Paula AM. Lip squamous cell carcinoma in a Brazilian population: epidemiological study and clinicopathological associations. Med Oral Patol Oral Cir Bucal 2011 Sep;16(6):e757-e762.

27. Savage NW, McKay C, Faulkner C. Actinic cheilitis in dental practice. Aust Dent J 2010 Jun;55(Suppl 1):78-84.

28. Araújo CP, Barros AC, Lima AA, Azevedo RA, Ramalho LM, Santos JN. Estudo histológico e histoquímico da elastose solar em lesões de queilite actínica. Rev Ci Méd Biol 2007; 6(2):152-159.

29. de Rosa I, Staibano S, Lo Muzio L, Delfino M, Lucariello A, Coppola A, De Rosa G, Scully C. Potentially malignant and malignant lesions of the lip. Role of silver staining nucleolar organizer regions, proliferating cell nuclear antigen, P53.and c-myc in differentiation and prognosis. J Oral Pathol Med 1999 Jul;28(6):252-258.

30. Fabbrocini G, Russo N, Pagliuca MC, Delfino M, Staibano S, Molea G, Mancini A, Virgili A, Valente MG, Bratina G, et al. P53, cyclin-D1, PCNA, AgNOR expression in squamous cell cancer of the lip: a multicenter study. Photodermatol Photoimmunol Photomed 2000 Aug;16(4):172-177. 